\title{
Access to bike lanes and childhood obesity: A systematic review and meta-analysis
}

\author{
Xiongfeng Pan $^{1,2}$ | Li Zhao ${ }^{3,4,2}$ | Jiayou Luo ${ }^{1,2}$ | Yinhao $\mathrm{Li}^{3}$ | Lin Zhang ${ }^{5,6,2}$ ( ) | \\ Tong $\mathrm{Wu}^{7,2}$ | Melody Smith ${ }^{8,2}$ \\ Shaoqing Dai ${ }^{9,2}$ () | Peng Jia, ${ }^{9,10,2}$ (c)
}

\author{
${ }^{1}$ Department of Maternal and Child Health, \\ Xiangya School of Public Health, Central South \\ University, Changsha, China \\ ${ }^{2}$ International Initiative on Spatial Lifecourse \\ Epidemiology (ISLE), Hong Kong, China \\ ${ }^{3}$ Department of Health Policy and \\ Management, West China School of Public \\ Health and West China Fourth Hospital, \\ Sichuan University, Chengdu, China \\ ${ }^{4}$ Research Center for Healthy City Development, \\ Sichuan University, Chengdu, China \\ ${ }^{5}$ Melbourne School of Population and Global \\ Health, University of Melbourne, Melbourne, \\ Victoria, Australia \\ ${ }^{6}$ Victorian Comprehensive Cancer Centre, The \\ University of Melbourne Centre for Cancer \\ Research, Melbourne, Victoria, Australia \\ ${ }^{7}$ Research Center for Eco-Environmental \\ Sciences, Chinese Academy of Sciences, \\ Beijing, China \\ ${ }^{8}$ School of Nursing, The University of \\ Auckland, Auckland, New Zealand \\ ${ }^{9}$ Faculty of Geo-information Science and Earth \\ Observation, University of Twente, Enschede, \\ the Netherlands \\ ${ }^{10}$ Department of Land Surveying and Geo- \\ Informatics, The Hong Kong Polytechnic \\ University, Hong Kong, China

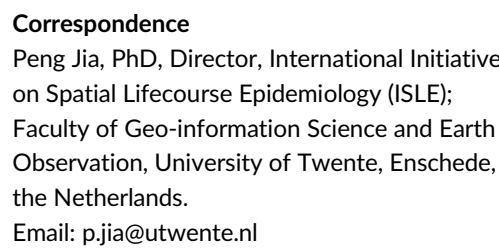
on Spatial Lifecourse Epidemiology (ISLE); Faculty of Geo-information Science and Earth Observation, University of Twente, Enschede, the Netherlands.

Email: p.jia@utwente.nl \\ Peng Jia, PhD, Director, International Initiative
}

Li Zhao, PhD, MPH, Department of Health

\section{Summary}

The lack of bike lane access has been a proven risk factor for childhood obesity due to its role in discouraging healthy lifestyles. However, there has not been a systematic review of this important association in the existing literature. This study aims to fill this gap. A literature search was conducted in the Cochrane Library, PubMed, Embase, and Web of Science for studies published from 1 January 2019 onwards that examined the association between bike lane access and weight-related behaviours and outcomes among children aged $<18$ years. A total of 21 studies were included in this systematic review. Among them, most of the studies showed that bike lane access was significantly associated with children and adolescents' physical activity (PA), whereas only two studies showed a negative association. Meta-analysis also supported these findings and showed that bike lane access was significantly associated with children and adolescents' PA (odds ratio $[O R]=1.57,95 \%$ confidence interval [Cl]: 1.37-1.81). Additionally, we reviewed how bike lane characteristics and microenvironment variables such as children and adolescents' choice of bicycle travel mode, the degree of separation of cycle path, cycle path unevenness, and street maintenance were associated with adolescents' preferences and intention to cycle. This systematic review and meta-analysis strongly suggests that bike lane access is associated with children and adolescents' PA. Nonetheless, it was difficult to draw a conclusion on the association between bike lane access and weight-related outcomes.

\section{KEYWORDS}

bike lane, built environment, child, obesity, overweight, physical activity 
Policy and Management, West China School of Public Health and West China Fourth Hospital, Sichuan University, Chengdu, China.

Email: zhaoli@scu.edu.cn

\section{Funding information}

State Key Laboratory of Urban and Regional

Ecology, Grant/Award Number:

SKLURE2018-2-5

\section{1 | INTRODUCTION}

Obesity is a leading cause of morbidity and premature mortality worldwide. In recent decades, the global prevalence of adult obesity has increased, from nearly $30 \%$ in 1980 to $40 \%$ in $2013 .{ }^{1}$ Furthermore, the global prevalence of obesity in children and adolescents increased from $0.7 \%$ to $5.6 \% .^{2}$ Obesity-related comorbidities for adults include cardiovascular disease, hypertension, type 2 diabetes mellitus, and certain cancers, ${ }^{3}$ as well as depression, anxiety, and low confidence. ${ }^{4-6}$ In children and adolescents, obesity is related with a higher risk of cardiovascular and cardiometabolic metabolic risk factors; pulmonary, endocrine, gastrointestinal, and musculoskeletal complications; lower quality of life and reduced psychological health. ${ }^{7,8}$ What is more, children and adolescents with obesity are more likely to be classified as being obese or overweight in adulthood. ${ }^{7,9}$ Lobstein and Jackson-Leach ${ }^{10}$ have estimated that by 2025 some 268 million children and adolescents aged 5-17 years may be overweight, including 91 million obese, assuming no policy interventions have proven effective at changing current trends. We have also estimated the likely numbers of children and adolescents in 2025 with obesity-related comorbidities: impaired glucose tolerance (12 million), type 2 diabetes (4 million), hypertension (27 million) and hepatic steatosis (38 million). ${ }^{10}$ Therefore, childhood obesity has become a major public health problem because of its health risks and fast-growing prevalence. As we all know, the rapid growth of the prevalence of childhood obesity is directly related to the poor lifestyle. Among them, lack of physical activity (PA) plays an important role in the occurrence and development of childhood obesity. ${ }^{11-13}$

The term 'obesogenic environment' has been coined and defined as the environmental factors that may increase children and adolescents' weight status. ${ }^{14}$ Such environments impact body size through enabling or hindering healthy eating and PA. Obesogenic environmental factors can be divided into macro-scale (e.g. connectivity and landuse mix) and micro-scale environmental factors (e.g. evenness of cycle path, presence of speed bumps, vegetation and environmental maintenance). ${ }^{15}$ Micro-scale environmental factors are easier to modify compared with macro-scale factors. ${ }^{15,16}$ Bike lanes, as a portion of the roadway, ${ }^{17}$ are one such factor. There are multiple aspects of bike lane design, including the density of bike lanes, proximity to the nearest bike lanes, width of bike lanes and other bike ability indices. ${ }^{18,19}$ Bike lane design and availability can indirectly influence childhood obesity through cycling behaviours, as it is assumed that a bikeable environment should encourage children and adolescents to conduct more PA such as cycling, ${ }^{20}$ which would be an important contributor to reducing rates of childhood overweight and obesity, within a broader socio-ecological context. ${ }^{21}$

Some studies have revealed an association between childhood obesity and the environmental factors that may support cycling. However, these study findings have been at a general level, often addressing this association using broader concepts of active transport infrastructure or behaviours (including overall PA) and remaining inconclusive in terms of effect direction and size. By way of example, Pont et $\mathrm{al}^{22}$ conducted a systematic review of the associations between environmental factors and active transportation, finding that bike lane access may be associated with higher rates of active transportation among young people aged 5-18 years. In previous studies, bike lane was only discussed as a subgroup variable, but no studies specifically examined cycling behaviours directly in relation to cycling infrastructure. ${ }^{22}$

Furthermore, Europe is developing active transportation policies to explore how environmental factors both positively and negatively influence cycling behaviors. ${ }^{23}$ However, associations of the policies promoting bike lane construction with PA are mixed, because many environmental and injury prevention policies have complex effects that have not been rigorously evaluated. It is necessary to conduct a systematic review of the relevant global research, in order to more robustly establish the relationship between bike lane access and childhood obesity.

This review aims to summarize the associations between bike lane access and childhood obesity. We tested our hypothesis that a lack, or lower level, of bike lane access was associated with lower levels of PA, higher levels of sedentary behaviours, and therefore greater weight among children and adolescents compared with their counterparts with greater bike lane access. ${ }^{24}$ Furthermore, we conducted a meta-analysis to quantify the association of bike lane access with childhood obesity and PA.

\section{METHODS}

We conducted a systematic review and meta-analysis based on the Cochrane Handbook 5.1.0, and the results of this systematic review and meta-analysis were reported in accordance with the Preferred Reporting Items for Systematic Reviews and MetaAnalyses (PRISRM). ${ }^{25}$ 


\section{1 | Eligibility criteria}

Studies that met all of the following criteria were included in the review: (1) study designs: experimental studies, cross-sectional studies and longitudinal studies including prospective and retrospective cohort studies; (2) study participants: children and adolescents aged $<18$ years; (3) exposures of interest: bike lanes (e.g. bike lanes access, length of bike lanes and availability of bike lanes); (4) study outcomes: weight-related behaviours (e.g. PA, sedentary behaviours) and/or outcomes (e.g. overweight or obesity measured by body mass index [BMI, $\mathrm{kg} / \mathrm{m}^{2}$ ] or waist circumference); (5) article types: peer-reviewed original research; (6) time of publication: from the inception of the given electronic bibliographic database to 1 January 2019 and (7) language: written in English.

\section{2 | Search strategy}

A keyword search was performed in four electronic bibliographic databases: Cochrane Library, PubMed, Embase, and Web of Science. The search strategy included all possible combinations of keywords from the three groups related to bike lanes, children and weight- related behaviours or outcomes. The specific search strategy is provided in Appendix S1.

Titles and abstracts of the articles identified through the keyword search were screened against the study selection criteria. Potentially relevant articles were retrieved for an evaluation of the full text. The reviewers L. Z. and Y. L. independently conducted the title and abstract screening and identified potentially relevant articles for the full-text review. Discrepancies were compiled by L. Z. and screened by two other reviewers X. P. and P. J. L. Z., Y.L., X. P. and J. P. jointly determined the list of articles for the full-text review through discussion. Then, L. Z. and Y. L. independently reviewed the full texts of all articles in the list and determined the final pool of articles included in the review. Figure 1 shows the search and filtering process.

\subsection{Data extraction and preparation}

A standardized data extraction form was used to collect methodological and outcome variables from each selected study, including authors, year of publication, country, sampling strategy, sample size, age at baseline, follow-up years, number of repeated measures, sample characteristics, statistical model, attrition rate, measures of

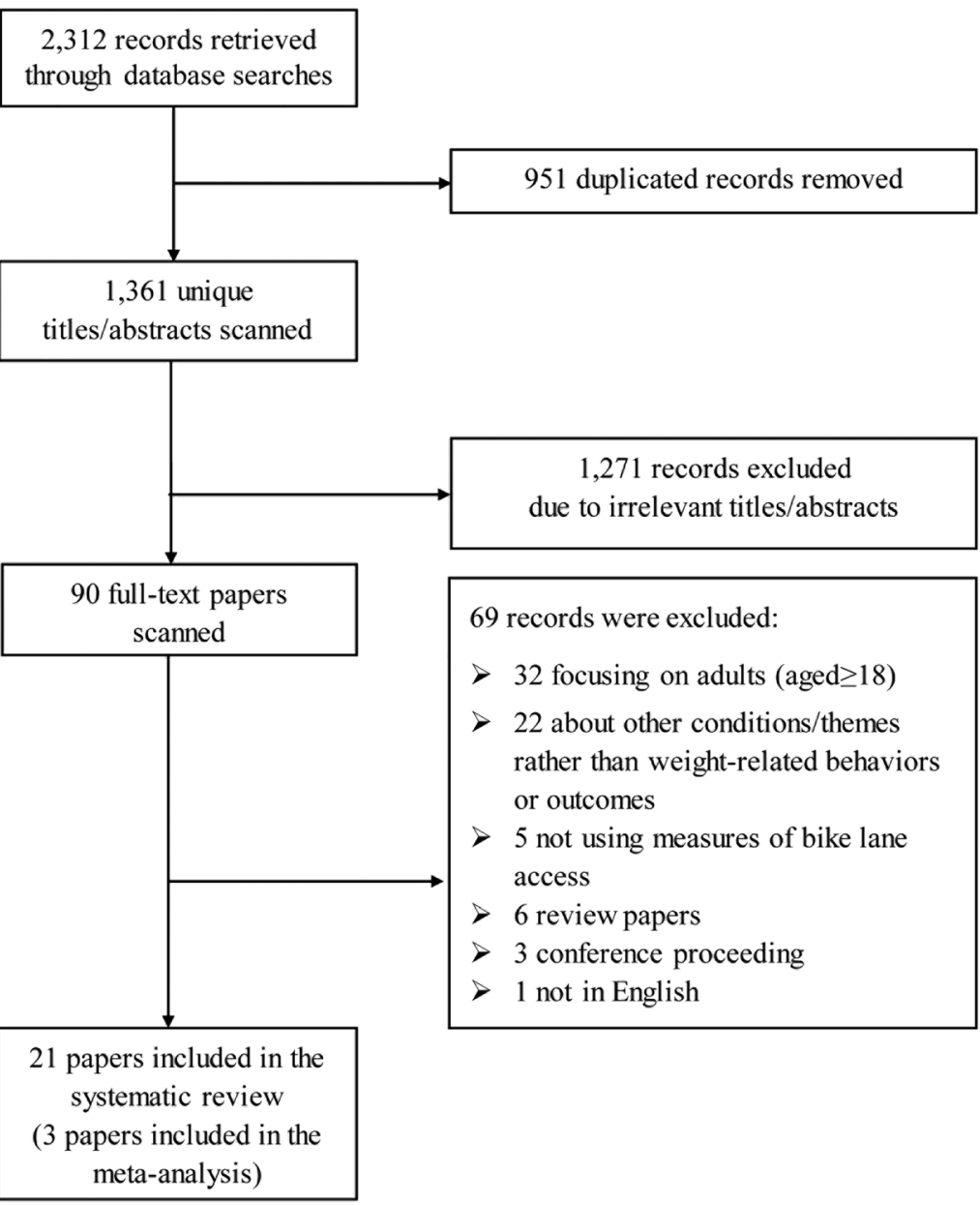


the bike lane access, measures of weight-related behaviours, measures of body-weight status and key findings on the association between bike lane access and weight-related behaviours and/or outcomes. L. Z. and Y. L. independently extracted data from each study included in the review, and discrepancies were resolved by X. P. and P. J.

\section{4 | Meta-analysis}

A meta-analysis was performed to estimate the pooled association size of bike lane access on each weight-related behaviour and outcome. Weight-related outcomes included BMI z-score, overweight status and obesity status. Overweight status (BMI at or above the 85th percentile) and obesity status (BMI at or above the 95th percentile) were based on the 2000 age-sex-specific Centers for Disease Control and Prevention Growth Charts. Weight-related behaviours included PA (e.g. cycling and active commuting to school), sedentary behaviours and diet. Several studies were excluded from the meta-analysis due to the following reasons: neither standard error nor confidence interval $(\mathrm{Cl})$ was reported; association size was unable to be transformed into a standardized coefficient (i.e. beta coefficient) due to the limited information reported; the unit of the association size was inconsistent with others and less than two studies reported the same outcome variable.

Study heterogeneity was assessed by using the $I^{2}$ index. The level of heterogeneity represented by $I^{2}$ was interpreted as modest $\left(I^{2} \leq 25 \%\right)$, moderate $\left(25 \%<I^{2} \leq 50 \%\right)$, substantial $\left(50 \%<I^{2} \leq 75 \%\right)$ or considerable $\left(I^{2}>75 \%\right) .{ }^{26}$ A fixed-association model was estimated when modest-to-moderate heterogeneity was present, and a randomassociation model was estimated when substantial-to-considerable heterogeneity was present. ${ }^{27}$ Publication bias was assessed by a visual inspection of the funnel plot and Begg's and Egger's tests to see if more than 10 studies were included. ${ }^{28}$ All meta-analyses were performed by the 'meta' packages using R software (Version R i386 3.4.2). ${ }^{29}$ All analyses used two-sided tests, and $p<0.05$ were considered statistically significant.

\section{5 | Study quality assessment}

We used the National Institutes of Health's Quality Assessment Tool for Observational Cohort and Cross-Sectional Studies to assess the quality of each included study. This assessment tool rates each study based on 14 criteria (Tables S3). For each criterion, a score of one was assigned if 'yes' was the response, whereas a score of zero was assigned otherwise (e.g. an answer of 'no', 'not applicable', 'not reported' or 'cannot determine'). A studyspecific global score ranging from 0 to 14 was calculated by summing up scores across all criteria. The study quality assessment helped measure the strength of scientific evidence but was not used to determine the inclusion of studies.

\section{3 | RESULTS}

\section{1 | Study selection}

Figure 1 shows the flowchart of study selection. We identified 2312 articles in three databases, and 1361 non-duplicated articles were included for the title and abstract screening. After excluding 1271 irrelevant records, the full texts of the remaining 90 articles were reviewed against the study selection criteria. A total of 21 studies were included in this systematic review. Some of them were excluded from the meta-analysis due to the following reasons: neither standard error nor $\mathrm{Cl}$ was reported ( $n=10$ ); the unit of association size (use $\beta$ instead of odds ratio [OR]) was inconsistent with others $(n=3)$ and less than two studies reported the same outcome variable $(n=5)$.

Table 1 summarizes the basic characteristics of the 21 included studies. All the studies were published between 2005 and 2018, with 14 cross-sectional studies, 2 longitudinal studies and 5 experimental studies (e.g. experimental study using manipulated photographs to find cycling-friendly environments for children). The sample size in these studies ranged widely from 53 to 1244862 . The largest number of studies was conducted in Belgium ( $n=6$ ), followed by the United States ( $n=4)$, Australia $(n=3)$ and the Netherlands $(n=3)$, and with one study each in Greece, Ireland, Spain, Sweden and the United Kingdom. Three of these studies were conducted at the national level, and the rest were conducted at the state $(n=8)$ and city $(n=10)$ levels.

Table S3 reports criterion-specific and global ratings from the National Institutes of Health's Quality Assessment Tool for Observational Cohort and Cross-Sectional Studies. The 21 studies scored between 9 and 14 with an average of 10.3 .

\subsection{Measures of bike lane access}

The bike lane access was measured by Geographic Information Systems (GIS) as the length of walking/cycling tracks within buffer zones centred on individual addresses or schools $(n=6)$, with varying radii (from 0.25 to $5 \mathrm{~km}$ ). The most commonly-used buffer zone was a $0.25-\mathrm{km}$ road-network buffer, followed by a $0.8-\mathrm{km}$ road-network buffer, a $0.5-\mathrm{km}$ road-network and a $5-\mathrm{km}$ road-network. In terms of the numbers of studies by methodology, experimental studies using manipulated photographs to investigate which micro-scale environmental factors determine children's or adolescents' preferences towards cycling for transport (e.g. evenness of cycle path including the categories of 'very uneven', 'moderately uneven' and 'even'; type of cycle path including the categories of 'no cycle path'; 'cycle path separated from traffic with lines', 'not separated from walking path', 'cycle path separated from traffic with a curb, not separated from walking path', 'cycle path separated from traffic with a hedge, not separated from walking path') ( $n=6$ ); cycling conditions by a checklist adapted from the Neighborhood Environment Walkability Scale (NEWS) $(n=2)$ and Assessing Levels of Physical Activity environmental (ALPHA) $(n=1)$; the presence of bike lanes by questionnaire $(n=2)$; the frequency of walk/bike path usage by questionnaire 
TABLE 1 Basic characteristics of the studies included

\begin{tabular}{|c|c|c|c|c|c|c|}
\hline $\begin{array}{l}\text { First author } \\
\text { (year) }\end{array}$ & $\begin{array}{l}\text { Study area, } \\
\text { country [scale] }\end{array}$ & $\begin{array}{l}\text { Study } \\
\text { design }\end{array}$ & $\begin{array}{l}\text { Sample } \\
\text { size (\% } \\
\text { of boys) }\end{array}$ & $\begin{array}{l}\text { Age at baseline } \\
(\text { years }+S D)^{a} \\
\text { or range (years) }\end{array}$ & $\begin{array}{l}\text { Sample characteristics } \\
\text { (follow-up status for } \\
\text { longitudinal studies) }\end{array}$ & $\begin{array}{l}\text { Statistical } \\
\text { model }\end{array}$ \\
\hline $\begin{array}{l}\text { Boarnet } \\
(2005)^{30}\end{array}$ & California, US [S1] & C & 862 (NA) & $\begin{array}{r}\text { Grades } 3-5 \text { in } \\
2002-2003\end{array}$ & $\begin{array}{c}\text { ECLS-K survey } \\
\text { participants }\end{array}$ & Two sample $t$ test \\
\hline $\begin{array}{l}\text { Carver } \\
\qquad(2015)^{31}\end{array}$ & Victoria, Australia [S1] & C & $640(49 \%)$ & $\begin{array}{l}\text { Aged } 11.6 \pm 2.0 \\
\text { in } 2010\end{array}$ & $\begin{array}{l}\text { The sample was recruited } \\
\text { for the Australian arm of } \\
\text { an international } \\
\text { comparison study of } \\
\text { children's independent } \\
\text { mobility. They are } 411 \\
\text { primary and } 229 \\
\text { secondary school-age } \\
\text { children. }\end{array}$ & Logistic regression \\
\hline $\begin{array}{l}\text { Chomitz } \\
\qquad(2011)^{33}\end{array}$ & Somerville, MA, US [C1] & C & 926 (49\%) & $\begin{array}{l}\text { Grades 6-8 in } \\
2007\end{array}$ & $\begin{array}{l}2007 \text { youth risk } \\
\text { surveillance survey } \\
\text { (YRBS) participants. } \\
\text { Middle school students } \\
\text { (grades 6-8). }\end{array}$ & $\begin{array}{l}\text { Multivariate logistic } \\
\text { regression }\end{array}$ \\
\hline $\begin{array}{l}\text { Estevan } \\
\qquad(2018)^{34}\end{array}$ & Valencia, Spain [C1] & C & $465(45 \%)$ & $\begin{array}{l}\text { Aged } 16.5 \pm 0.8 \\
\text { in 2013-2015 }\end{array}$ & $\begin{array}{l}\text { International Physical } \\
\text { Activity and the } \\
\text { Environment Network } \\
\text { (IPEN) adolescent study } \\
\text { participants. Students } \\
\text { from nine high schools. }\end{array}$ & $\begin{array}{l}\text { Mixed associations } \\
\text { regression models }\end{array}$ \\
\hline $\begin{array}{l}\text { Ghekiere } \\
\qquad(2016)^{36}\end{array}$ & Melbourne, Australia [C1] & C & $677(47 \%)$ & Aged $11.5 \pm 0.6$ & $\begin{array}{l}\text { Children Living in Active } \\
\text { Neighborhoods (CLAN) } \\
\text { study participants. } \\
\text { Students from } 19 \\
\text { primary schools. }\end{array}$ & $\begin{array}{l}\text { Multilevel linear } \\
\text { regressions }\end{array}$ \\
\hline $\begin{array}{l}\text { Ghekiere } \\
\qquad(2018)^{37}\end{array}$ & Flanders, Belgium [S1] & $\mathrm{E}$ & $\begin{array}{l}1289 \\
(49 \%)\end{array}$ & $\begin{array}{c}\text { Aged } 10-12 \text { in } \\
2014-2015\end{array}$ & $\begin{array}{l}\text { Students (grades 5-6) } \\
\text { from } 45 \text { primary school } \\
\text { located across Flanders. }\end{array}$ & $\begin{array}{l}\text { Hierarchical Bayes } \\
\text { estimation }\end{array}$ \\
\hline $\begin{array}{l}\text { Helbich } \\
\qquad(2016)^{38}\end{array}$ & $\begin{array}{l}\text { Amersfoort, Haarlem, } \\
\text { Hengelo, Rotterdam, } \\
\text { Vlaardingen, } \\
\text { Netherlands [C5] }\end{array}$ & C & 97 (40\%) & $\begin{array}{l}\text { Aged 6-11 in } \\
2008-2009\end{array}$ & $\begin{array}{l}\text { Part of 'Spatial Planning } \\
\text { and Children's Exercise' } \\
\text { (SPACE) project. } \\
\text { Students from six } \\
\text { elementary schools } \\
\text { located in five } \\
\text { neighbourhoods in } \\
\text { mid-to large-sized } \\
\text { Dutch cities. }\end{array}$ & $\begin{array}{l}\text { Generalized linear mixed } \\
\text { models and Spearman's } \\
\text { correlation }\end{array}$ \\
\hline $\begin{array}{l}\text { Kamargianni } \\
(2015)^{39}\end{array}$ & Greece and Cyprus[N2] & C & $\begin{array}{l}9554 \\
(48 \%)\end{array}$ & $\begin{array}{l}\text { Aged } 15.7 \text { in } \\
2012-2013\end{array}$ & $\begin{array}{l}\text { Students from public high } \\
\text { schools in different } \\
\text { types of cities (urban, }\end{array}$ & Logistic mixture model \\
\hline
\end{tabular}


TABLE 1 (Continued)

\begin{tabular}{|c|c|c|c|c|c|c|}
\hline $\begin{array}{l}\text { First author } \\
\text { (year) }\end{array}$ & $\begin{array}{l}\text { Study area, } \\
\text { country [scale] }\end{array}$ & $\begin{array}{l}\text { Study } \\
\text { design }\end{array}$ & $\begin{array}{l}\text { Sample } \\
\text { size ( } \% \\
\text { of boys) }\end{array}$ & $\begin{array}{l}\text { Age at baseline } \\
{\text { (years }+\mathrm{SD})^{\mathrm{a}}} \\
\text { or range (years) }\end{array}$ & $\begin{array}{l}\text { Sample characteristics } \\
\text { (follow-up status for } \\
\text { longitudinal studies) }\end{array}$ & $\begin{array}{l}\text { Statistical } \\
\text { model }\end{array}$ \\
\hline & & & & & $\begin{array}{l}\text { rural and insular) of two } \\
\text { different countries. }\end{array}$ & \\
\hline Lee $(2017)^{40}$ & Austin, Texas, US,[C1] & $\mathrm{E}$ & 165 (50\%) & $\begin{array}{l}\text { Grades } 1-5 \text { in } \\
2011\end{array}$ & $\begin{array}{l}\text { Elementary students from } \\
\text { a new school that } \\
\text { opened in late August } \\
2010 .\end{array}$ & $\begin{array}{l}\text { Binomial logistic } \\
\text { regression }\end{array}$ \\
\hline $\begin{array}{l}\text { Mandic } \\
\qquad(2017)^{41}\end{array}$ & $\begin{array}{l}\text { Dunedin, New Zealand } \\
\text { [C1] }\end{array}$ & C & $764(45 \%)$ & $\begin{array}{l}\text { Aged 13-18 } \\
\begin{array}{l}(15.2 \pm 1.4) \text { in } \\
2014-2015\end{array}\end{array}$ & $\begin{array}{l}\text { Built Environment and } \\
\text { Active Transport to } \\
\text { School (BEATS) study } \\
\text { participants. Students } \\
\text { from } 12 \text { secondary } \\
\text { schools. }\end{array}$ & $\begin{array}{l}\text { Mean (SD) and frequency } \\
(\%)\end{array}$ \\
\hline $\begin{array}{l}\text { Oliveira } \\
\qquad(2018)^{43}\end{array}$ & $\begin{array}{l}\text { Northern region of } \\
\text { Portugal }[\mathrm{N}]\end{array}$ & $\mathrm{L}$ & $583(49 \%)$ & $\begin{array}{l}\text { Aged 12-18 } \\
\quad(14.28 \pm 1.79) \\
\text { in 2011-2013 }\end{array}$ & $\begin{array}{l}\text { Part of the longitudinal } \\
\text { analysis of biomarkers } \\
\text { and environmental } \\
\text { determinants of physical } \\
\text { activity (lab med } \\
\text { physical activity study). } \\
\text { (followed up from } 2011 \\
\text { to } 2013 \text { with two } \\
\text { repeated measures) }\end{array}$ & Linear regression \\
\hline $\begin{array}{r}\text { Verhoeven } \\
(2018)^{46}\end{array}$ & Flanders, Belgium [S1] & $E$ & $882(55 \%)$ & $\begin{array}{l}\text { Aged } 12-16 \\
(13.9 \pm 1.6) \text { in } \\
2016\end{array}$ & $\begin{array}{l}\text { Students from } 12 \\
\text { secondary schools } \\
\text { across Flanders. }\end{array}$ & $\begin{array}{l}\text { Hierarchical Bayes } \\
\text { estimation }\end{array}$ \\
\hline $\begin{array}{r}\text { Verhoeven } \\
(2018)^{47}\end{array}$ & $\begin{array}{l}\text { Ghent, Flanders, Belgium } \\
\text { [C1] }\end{array}$ & $\mathrm{C}$ & $204(47 \%)$ & $\begin{array}{l}\text { Aged } 12-16 \\
(14.4 \pm 1.2) \text { in } \\
2015\end{array}$ & $\begin{array}{l}\text { Students (grade1-4) from } \\
\text { six secondary schools in } \\
\text { and around Ghent. }\end{array}$ & $\begin{array}{l}\text { Univariate multilevel } \\
\text { logistic regression } \\
\text { analyses }\end{array}$ \\
\hline $\begin{array}{l}\text { Vries } \\
\qquad(2007)^{48}\end{array}$ & Netherlands [C6] & C & 422 (49\%) & $\begin{array}{l}\text { Aged 6-11 (8.3 } \\
\quad \pm 1.4) \text { in } \\
2004-2005\end{array}$ & $\begin{array}{l}\text { Part of the Spatial } \\
\text { Planning and Children's } \\
\text { Exercise (SPACE) study. } \\
\text { Students from } 20 \\
\text { elementary schools. }\end{array}$ & $\begin{array}{l}\text { Univariate and } \\
\text { multivariate linear } \\
\text { regression }\end{array}$ \\
\hline $\begin{array}{l}\text { Weimann } \\
(2015)^{49}\end{array}$ & Scandinavia, Sweden [S1] & C & $205(50 \%)$ & $\begin{array}{l}\text { Aged 4-11 (8.5 } \\
\quad \pm 1.6) \text { in } \\
2009-2010\end{array}$ & $\begin{array}{l}\text { Part of Identification and } \\
\text { Prevention of Dietary- } \\
\text { and Lifestyle-Induced } \\
\text { Health Associations in } \\
\text { Children and Infants } \\
\text { (IDEFICS) study. They } \\
\text { from } 168 \text { families. }\end{array}$ & Mixed linear regression \\
\hline
\end{tabular}

Note. Scale: [N] - National; [S] - State (e.g. in the United States) or equivalent unit (e.g. province in China, Canada); [Sn] - $n$ states or equivalent units; [CT] - County or equivalent unit; [CTn] - $n$ counties or equivalent units; [C] - City; [Cn] - $n$ cities.

Abbreviations: C, cross-sectional; E, experimental; L, longitudinal.

${ }^{\mathrm{a}} \mathrm{NA}=$ Not available. 
( $n=2$ ); the presence of bike lanes by self-reporting $(n=1)$ and the availability of bike lanes by questionnaire ( $n=1$; Table S1).

\subsection{Association between bike lane access and weight-related behaviours}

Twenty studies examined the association between bike lane access and weight-related behaviours, including those that only measured PA ( $n=19$ ) and mixed findings that measured both PA and sedentary behaviour ( $n=1$; Table S2). When PA was used as the outcome variable, 10 studies reported the relationship between bike lane access and children's PA, such as active commuting to school, active commuting to home and cycling for leisure purpose. Among them, six studies reported a significant positive correlation between bike lane access and children's sports activities. ${ }^{31,32,38,39,42,48}$ Two studies reported that there was no significant correlation between bicycle tracks and children's PA. ${ }^{34,36}$ One study reported a significant negative correlation between bike lane access and children's sports activities. ${ }^{40}$ One study reported that bike path usage was significantly associated with moderate PA but not associated with vigorous PA. ${ }^{33}$ Six studies reported the relationship between bike lane access and children's preferences and intention to cycle. ${ }^{15,35,37,44,46,47}$ The degree of separation of cycle path, evenness of cycle path and street maintenance were associated with adolescents' preferences and intention to cycle for transport. Three studies found that parents or children reported that bike lane access was an important condition for children's PA. ${ }^{30,41,45}$ One study reported that children with low access to bike paths had more sedentary time than those with medium or high access. ${ }^{49}$

Figure 2 summarizes the modelling results from the meta-analysis. It shows the forest plot of change in children's PA in response to bike lane access with OR. A meta-analysis was conducted to estimate the pooled estimation size of the association between measures of bike lane access and PA outcomes. We observed significant association in the meta-analyses $(O R=1.57$, $95 \% \mathrm{Cl}: 1.37-1.81)$ and with moderate heterogeneity $\left(I^{2}=38 \%\right)$.

\subsection{Association between bike lane access and weight-related outcomes}

One study reported that the presence of bike lanes was associated with a lower BMI and waist circumference in girls; the availability of bike lanes was associated with a higher BMI and waist circumference in boys. ${ }^{43}$ The study also showed that perceptions of distant facilities at baseline were associated with lower fitness at follow-up in boys. Also, the positive perception of a pleasant environment at baseline was associated with better fitness at follow-up among boys. Additionally, for girls, higher bike lane availability and positive aesthetic perception at baseline were associated with healthier body composition at follow-up.

\section{4 | DISCUSSION}

The aim of this research was to systematically review the association between bike lane access and childhood obesity. We identified and systematically reviewed 21 studies that assessed the association between the bike lane access and weight-related behaviours and outcomes in children and adolescents. We included 14 cross-sectional studies, 2 longitudinal studies and 5 experimental studies. The majority of studies measured bike lane access using GIS-based measures, and PA was the most commonly studied outcome variable. Mixed results were observed for this association across the studies. Although only a few studies reported null associations for weight-related behaviour/outcomes with increased bike lane access, most of the studies reported positive associations for children's weight-related behaviour/outcomes with increased bike lane access. Our metaanalysis also found that the availability of bike lanes was associated with PA among children.

Overall, our results showed that children's increased active transportation and PA were related to bike lane access. This may suggest that as the presence of bike lanes increase, so does the likelihood that children or their parents will choose to cycle, which has considerable potential for increasing health promoting levels of

\begin{tabular}{lllllrr} 
Study & OR & \multicolumn{2}{c}{$\begin{array}{c}\text { Weight } \\
\text { (fixed) }\end{array}$ Weight } \\
(random)
\end{tabular}

FIGURE 2 Forest plot of changes in children's physical activity in response to bike lane access with OR. OR, Odds ratio; Norah M. Nelson (2010 A): Male; Norah M. Nelson (2010 B): Female; Virginia Rall Chomitz (2011 A): Moderate Physical Activity; Virginia Rall Chomitz (2011 B): Vigorous Physical Activity; Virginia Rall Chomitz (2011 C):60+Minutes Physical Activity Appendix A. Search strategy and search results 
PA. It is widely accepted that the neighbourhood environment may interact with personal characteristics to affect individual weight status and, at times, even outweigh personal factors. ${ }^{16}$ The elements external to the individual that are involved in the development of obesity have become known as the obesogenic environment. ${ }^{50}$ A systematic map of reviews on social and environmental interventions to reduce childhood obesity identified a need for reviews focusing on interventions or changes to the built environment. $^{51}$ Meanwhile, our result is consistent with other previous reviews. For instance, Pont et al ${ }^{22}$ found a possible positive correlation between children's active transportation and recreational facilities, bicycles and/or walking facilities near home. Lorenc et al 52 found a positive correlation between the presence of walking and/or bike paths and PA among children.

Interestingly, Lee et al ${ }^{40}$ found a significant negative correlation between bike lanes and children's sports activities, which may be caused by a small sample size $(n=465)$. Smith et $a^{53}$ found parental licence for independent mobility was only associated with a need for safer places to cycle (positive) and objectively assessed cycling infrastructure (negative) in adjusted models. This finding could be due to parents allowing their children to be independently mobile, but more so for walking rather than cycling. ${ }^{53}$ Moreover, PA was measured using questionnaires, which can lead to recall bias, thus affecting the final results. At the same time, Ghekiere et al ${ }^{36}$ and Estevan et al ${ }^{34}$ reported an insignificant correlation between bike lane access and children's sports activities, which may also be caused by a small sample size ( 677 and 165 , respectively). In addition, the linear regression model used by Ghekiere et al ${ }^{36}$ did not adjust for related confounding. We believe that this may also be a negative result caused by study bias, which needs to be further expanded for verification.

On the other hand, a review by Harrison and Jones ${ }^{54}$ supports our results from another perspective. They found that children attending schools with the best nearby conditions for walking and cycling (e.g. cycle lanes and traffic calming) spent more time in PA during commuting times to and from school compared with those at schools that have the worst provision. Fraser and Lock ${ }^{19}$ found a positive correlation between commuting by bike and bike lane access. This is also consistent with our results, which indicate that parents or children reported bike lane access to be an important condition for children's PA. More directly, our results showed that bike lane access was not only associated with children's activities but also with obesity levels in children. Our results showed that the presence of bike lanes was associated with a lower BMI and waist circumference for girls but a higher $\mathrm{BMI}$ and waist circumference for boys. Nonetheless, it was difficult to draw a firm conclusion about the association between bike lane access and $\mathrm{BMI} /$ waist circumference.

Logically, after observing the results related to bike lane access and children's activities, it was important to further explore how specific micro-environment factors related to children's PA. Our results show that bike lanes that were well-separated and good maintenance are likely to encourage adolescents to cycle. It is also important to note that cycling infrastructure is an important factor that may positively influence children's cycling. For example, Giles-Corti et al ${ }^{55}$ found that improving micro-scale attributes may increase the suitability of a street for children's cycling activities, such as improving wellseparated of bike lane, even of bike lane and good maintenance of bike lane.

To advance the research on the association between the bike lane access and children's weight-related behaviours and outcomes, future studies should overcome or mitigate several limitations of this study. First, objective measurement should be conducted in a more precise and consistent way, for example, using GIS-based road-network distance and a set of radii $a$ priori for better comparability and better reporting of methods. ${ }^{56,57}$ More advanced spatial approaches, such as remote sensing and citizen science, ${ }^{5859}$ are alternative methods to obtain such environmental measures where GIS-based road-network are not available. ${ }^{60,61}$ Second, some novel objective measures and subjective measures should be added to measure all dimensions of bike lane access and its affiliated microenvironment, such as evenness of the cycle path and the degree of separation of cycle paths. Third, more pathway-based analyses need to be conducted to elucidate underlying mechanisms from bike lane access in individual's home and/or school neighbourhoods to child weight-related behaviours and outcomes. For example, greater bike lane access would also increase the access to food venues in the neighbourhood, including both healthful and unhealthful ones. ${ }^{24,62}$ The actual pathway from bike lane access through PA to weight-related outcomes may be affected by the neighbourhood food environment and hence may be more complex than our hypothesis. However, these research questions need to be answered in longitudinal study designs that account for multiple levels of influence on body size outcomes across the socioecological model. ${ }^{63,64}$ Lastly, bike lanes may have different degrees of completeness across regions or be occupied by vehicles (or parking) and/or pedestrians, which could all affect the actual utilization of bike lanes and the association between bike lane access and children's PA and weight status through factors such as parental perception of road or neighbourhood safety for cycling. ${ }^{65}$ Moreover, the emerging bike-sharing systems (widely popular in many cities and countries already) are another important factor that could make the utilization of bike lanes different from traditional scenarios where bikes are owned exclusively by individuals. $^{66,67}$ Therefore, changes in the perceptions and behaviours of cyclers could also be an important research consideration.

\section{5 | CONCLUSIONS}

Although most studies included in this systematic review and meta-analysis revealed a positive association between bike lane access and PA of children and adolescents, it was difficult to draw a conclusion on the association between bike lane access and weight-related outcomes. However, according to many reasonable scientific hypotheses and evidence from some high-quality research, improving bike infrastructure and the relevant 
microenvironment may be an effective way to improve the support for children and adolescents to cycle safely outdoors and engage in more PA. Such actions would also help us design more longitudinal studies to further elucidate the association between bike lane access and children's obesity.

\section{ACKNOWLEDGEMENTS}

This study is supported by research grants from the State Key Laboratory of Urban and Regional Ecology of China (SKLURE2018-2-5). Peng Jia, Director of the International Initiative on Spatial Lifecourse Epidemiology (ISLE), thanks the Netherlands Organization for Scientific Research, the Royal Netherlands Academy of Arts and Sciences, the Chinese Center for Disease Control and Prevention, and the West China School of Public Health and West China Fourth Hospital in Sichuan University for funding the ISLE and supporting ISLE's research activities.

\section{CONFLICT OF INTEREST}

We declare no conflicts of interest.

\section{ORCID}

Lin Zhang (D) https://orcid.org/0000-0002-2064-8440

Shaoqing Dai (ID https://orcid.org/0000-0003-0858-4728

Peng Jia (D) https://orcid.org/0000-0003-0110-3637

\section{REFERENCES}

1. $\mathrm{Ng} M$, Fleming $T$, Robinson $M$, et al. Global, regional, and national prevalence of overweight and obesity in children and adults during 1980-2013: a systematic analysis for the global burden of disease study 2013. The Lancet. 2014;384(9945):766-781.

2. Abarca-Gómez L, Abdeen ZA, Hamid ZA, et al. Worldwide trends in body-mass index, underweight, overweight, and obesity from 1975 to 2016: a pooled analysis of 2416 population-based measurement studies in 128 ; 9 million children, adolescents, and adults. The Lancet. 2017;390:2627-2642.

3. Guh DP, Zhang W, Bansback N, Amarsi Z, Birmingham CL, Anis AH. The incidence of co-morbidities related to obesity and overweight: a systematic review and meta-analysis. BMC Public Health. 2009; 9(1):88.

4. Hatzenbuehler ML, Keyes KM, Hasin DS. Associations between perceived weight discrimination and the prevalence of psychiatric disorders in the general population. Obesity. 2009;17(11):2033-2039.

5. Puhl R, Suh Y. Stigma and eating and weight disorders. Curr Psychiatry Rep. 2015;17:10.

6. Vartanian LR, Novak SA. Internalized societal attitudes moderate the impact of weight stigma on avoidance of exercise. Obesity. 2011; 19(4):757-762.

7. Kumar S, Kelly AS. Review of childhood obesity: from epidemiology, etiology, and comorbidities to clinical assessment and treatment. Mayo Clin Proc. 2017;92(2):251-265.

8. Pulgarón ER. Childhood obesity: a review of increased risk for physical and psychological comorbidities. Clin Ther. 2013;35(1): A18-A32.

9. Singh AS, Mulder C, Twisk JWR, Van Mechelen W, Chinapaw MJM. Tracking of childhood overweight into adulthood: a systematic review of the literature. Obes Rev. 2008;9(5):474-488.

10. Lobstein T, Jackson-Leach R. Planning for the worst: estimates of obesity and comorbidities in school-age children in 2025. Pediatr Obes. 2016;11(5):321-325.
11. Jia P, Xue H, Zhang J, Wang Y. Time trend and demographic and geographic disparities in childhood obesity prevalence in China-evidence from twenty years of longitudinal data. Int J Environmen Res Public Health. 2017;14(4):369.

12. Ogden CL, Fryar CD, Hales CM, Carroll MD, Aoki Y, Freedman DS. Differences in obesity prevalence by demographics and urbanization in US children and adolescents, 2013-2016. JAMA. 2018;319(23): 2410-2418.

13. Tylavsky FA, Ferrara A, Catellier DJ, et al. Understanding childhood obesity in the US: the NIH environmental influences on child health outcomes (ECHO) program. Int J Obes (Lond). 2005;2019(3):617627. https://doi.org/10.1038/s41366-019-0470-5

14. Jia $P$, Cheng $X, X u e ~ H$, Wang Y. Applications of geographic information systems (GIS) data and methods in obesity-related research. Obes Rev. 2017;18(4):400-411.

15. Ghekiere A, Deforche B, Mertens L, et al. Creating cycling-friendly environments for children: which micro-scale factors are most important? An Experimental Study Using Manipulated Photographs PLoS One. 2015;10:e0143302.

16. Jia $\mathrm{P}$, Xue H, Cheng $\mathrm{X}$, Wang $\mathrm{Y}$, Wang $\mathrm{Y}$. Association of neighborhood built environments with childhood obesity: evidence from a 9-year longitudinal, nationally representative survey in the US. Environ Int. 2019;128:158-164.

17. National Association of City Transportation O. Urban Bikeway Design Guide. Island Press; 2014.

18. Muhs CD, Clifton K. Do characteristics of walkable environments support bicycling? Toward a definition of bicycle-supported development. Journal of Transport and Land Use. 2016.

19. Fraser SD, Lock K. Cycling for transport and public health: a systematic review of the effect of the environment on cycling. Eur J Public Health. 2011;21(6):738-743.

20. De Vries SI, Hopman-Rock M, Bakker I, Hirasing RA, Van Mechelen W. Built environmental correlates of walking and cycling in Dutch urban children: results from the SPACE study. Int J Environ Res Public Health. 2010;7:2309-2324.

21. Gascon M, Vrijheid M, Nieuwenhuijsen MJ. The built environment and child health: an overview of current evidence. Current Environmental Health Reports. 2016;3(3):250-257.

22. Pont K, Ziviani J, Wadley D, Bennett S, Abbott R. Environmental correlates of children's active transportation: a systematic literature review. Health Place. 2009;15(3):827-840.

23. Fraser SDS, Lock K. Cycling for transport and public health: a systematic review of the effect of the environment on cycling. Eur J Public Health. 2010;21:738-743.

24. Smith M, Obolonkin V, Plank L, et al. The importance of pedestrian network connectivity for adolescent health: a cross-sectional examination of associations between neighbourhood built environments and metabolic health in the Pacific Islands families birth cohort study. Int J Environ Res Public Health. 2019;16:3375.

25. Panic N, Leoncini E, de Belvis G, Ricciardi W, Boccia S. Evaluation of the endorsement of the preferred reporting items for systematic reviews and meta-analysis (PRISMA) statement on the quality of published systematic review and meta-analyses. PLoS One. 2013;8: e83138.

26. Pan X, Kaminga AC, Wen SW, Liu A. Catecholamines in posttraumatic stress disorder: a systematic review and meta-analysis. Front Mol Neurosci. 2018;11:450.

27. Pan X, Wang Z, Wu X, Wen SW, Liu A. Salivary cortisol in posttraumatic stress disorder: a systematic review and meta-analysis. BMC Psychiatry. 2018;18:324.

28. Egger M, Davey Smith G, Schneider M, Minder C. Bias in metaanalysis detected by a simple, graphical test. BMJ (Clinical research ed). 1997;315:629-634.

29. Pan X, Wu X, Kaminga AC, Wen SW, Liu A. Dehydroepiandrosterone and dehydroepiandrosterone sulfate in Alzheimer's disease: a 
systematic review and meta-analysis. Front Aging Neurosci. 2019; 11:61.

30. Boarnet MG, Anderson CL, Day K, McMillan T, Alfonzo M. Evaluation of the California safe routes to school legislation: urban form changes and children's active transportation to school. Am J Prev Med. 2005; 28(2 Suppl 2):134-140.

31. Carver A, Timperio AF, Crawford DA. Bicycles gathering dust rather than raising dust-prevalence and predictors of cycling among Australian schoolchildren. J Sci Med Sport. 2015;18(5):540-544.

32. Chen P, Jiao J, Xu M, Gao X, Bischak C. Promoting active student travel: a longitudinal study. Journal of Transport Geography. 2018;70: 265-274

33. Chomitz VR, Aske DB, McDonald J, Cabral H, Hacker KA. The role of recreational spaces in meeting physical activity recommendations among middle school students. J Phys Act Health. 2011;8:S8-S16.

34. Estevan I, Queralt A, Molina-Garcia J. Biking to school: the role of bicycle-sharing programs in adolescents. J Sch Health. 2018;88(12): 871-876.

35. Ghekiere A, Van Cauwenberg J, Mertens L, et al. Assessing cyclingfriendly environments for children: are micro-environmental factors equally important across different street settings? Int J Behav NutriPhys Acti. 2015;12:54.

36. Ghekiere A, Carver A, Veitch J, Salmon J, Deforche B, Timperio A. Does parental accompaniment when walking or cycling moderate the association between physical neighbourhood environment and active transport among 10-12 year olds? J Sci Med Sport. 2016;19(2): 149-153.

37. Ghekiere A, Deforche B, De Bourdeaudhuij I, et al. An experimental study using manipulated photographs to examine interactions between micro-scale environmental factors for children's cycling for transport. J Trans Geog. 2018;66:30-34

38. Helbich M, Emmichoven MJ, Dijst MJ, Kwan MP, Pierik FH, Vries SI. Natural and built environmental exposures on children's active school travel: a Dutch global positioning system-based cross-sectional study. Health Place. 2016;39:101-109.

39. Kamargianni M. Investigating next generation's cycling ridership to promote sustainable mobility in different types of cities. Research in Transportation Economics. 2015;53:45-55.

40. Lee C, Yoon J, Zhu X. From sedentary to active school commute: multi-level factors associated with travel mode shifts. Prev Med. 2017;95(Suppl):S28-s36.

41. Mandic S, Hopkins D, García Bengoechea E, et al. Adolescents' perceptions of cycling versus walking to school: understanding the New Zealand context. J Transp Health. 2017;4:294-304.

42. Nelson NM, Foley E, O'Gorman DJ, Moyna NM, Woods CB, et al. Active commuting to school: How far is too far? Int J Behav Nutri Phys Acti. 2008;5.

43. Oliveira A, Lopes L, Abreu S, et al. Environmental perceptions and its associations with physical fitness and body composition in adolescents: longitudinal results from the LabMed physical activity study. Int J Adolesc Med Health. 2018.

44. Veitch J, Salmon J, Deforche B, et al. Park attributes that encourage park visitation among adolescents: a conjoint analysis. Landscape Urban Plan. 2017;161:52-58.

45. Verhoeven $\mathrm{H}$, Ghekiere A, Van Cauwenberg J, et al. Which physical and social environmental factors are most important for adolescents' cycling for transport? An experimental study using manipulated photographs. Int J Behav Nutr Phys Act. 2017;14:108.

46. Verhoeven H, Ghekiere A, Van Cauwenberg J, et al. Subgroups of adolescents differing in physical and social environmental preferences towards cycling for transport: a latent class analysis. Prev Med. 2018; 112:70-75.

47. Verhoeven $\mathrm{H}$, Van Hecke L, Van Dyck D, et al. Differences in physical environmental characteristics between adolescents' actual and shortest cycling routes: a study using a Google street view-based audit. Int J Health Geogr. 2018;17:16.

48. de Vries SI, Bakker I, van Mechelen W, Hopman-Rock M. Determinants of activity-friendly neighborhoods for children: results from the SPACE study. Am J Health Promot. 2007;21(4 Suppl): 312-316.

49. Weimann H, Bjork J, Rylander L, Bergman P, Eiben G. Neighborhood environment and physical activity among young children: a crosssectional study from Sweden. Scand J Public Health. 2015;43(3): 283-293.

50. Swinburn B, Egger G, Raza F. Dissecting obesogenic environments: the development and application of a framework for identifying and prioritizing environmental interventions for obesity. Prev Med. 1999; 29(6 Pt 1):563-570.

51. Woodman J, Harden A, Thomas J, Brunton J, Kavanagh J, Stansfield C. Searching for systematic reviews of the effects of social and environmental interventions: a case study of children and obesity. Journal of the Medical Library Association: JMLA. 2010;98(2): 140-146.

52. Lorenc T, Brunton G, Oliver S, Oliver K, Oakley A. Attitudes to walking and cycling among children, young people and parents: a systematic review. J Epidemiol Community Health. 2008;62(10): 852-857.

53. Smith M, Amann R, Cavadino A, et al. Children's transport built environments: a mixed methods study of associations between perceived and objective measures and relationships with parent licence for independent mobility in Auckland, New Zealand. Int J Environ Res Public Health. 2019;16.

54. Harrison F, Jones AP. A framework for understanding school based physical environmental influences on childhood obesity. Health Place. 2012;18(3):639-648.

55. Giles-Corti B, Kelty SF, Zubrick SR, Villanueva KP. Encouraging walking for transport and physical activity in children and adolescents: how important is the built environment? Sports medicine (Auckland, NZ). 2009;39:995-1009.

56. Jia $P$, Xue H, Yin L, Stein A, Wang M, Wang Y. Spatial technologies in obesity research: current applications and future promise. Trends in Endocrinology and Metabolism: TEM. 2019;30(3):211-223.

57. Jia P, Yu C, Remais JV, et al. Spatial lifecourse epidemiology reporting standards (ISLE-ReSt) statement. Health Place. 2019;102243.

58. Jia $\mathrm{P}$, Stein A. Using remote sensing technology to measure environmental determinants of non-communicable diseases 2017; 46: 1343 .

59. Jia P, Stein A, James P, et al. Earth observation: investigating noncommunicable diseases from space. Annual Review of Public Health 40:85-104.

60. Jia P. Integrating kindergartener-specific questionnaires with citizen science to improve child health. Frontiers in Public Health. 6:1-4.

61. Shiffman S, Hufford MR. Ecological momentary assessment. Annu Rev Clin Psychol. 2001;4:1-32.

62. Jia P, Zou Y, Wu Z, et al. Street connectivity, physical activity, and childhood obesity: a systematic review and meta-analysis. Obes Rev. 2019.

63. Jia P. Spatial lifecourse epidemiology. The Lancet Planetary Health. 3 : e57-e59.

64. Jia P, Lakerveld J, Wu J, et al. Top 10 research priorities in spatial Lifecourse epidemiology. Environ Health Perspect. 2019;127:7450174501.

65. Smith M, Witten K, Field A, et al. The pathway to behaviour change: preliminary findings from Te Ara Mua-future streets (high scoring researcher abstract award sponsored by The Institute of Transportation Engineers). J Transp Health. 2019;14:S21-S22.

66. Hu Y, Zhang Y, Lamb D, Zhang M, Jia P. Examining and optimizing the BCycle bike-sharing system-a pilot study in Colorado, US. Applied Energy. 247:1-12. 
67. Zhang L, Zhang J, Duan Z-Y, Bryde D. Sustainable bike-sharing systems: characteristics and commonalities across cases in urban China. J Clean Prod. 2015;97:124-133.

\section{SUPPORTING INFORMATION}

Additional supporting information may be found online in the Supporting Information section at the end of this article.
How to cite this article: Pan X, Zhao L, Luo J, et al. Access to bike lanes and childhood obesity: A systematic review and meta-analysis. Obesity Reviews. 2020;1-11. https://doi.org/ 10.1111/obr.13042 


\section{University Library}

\section{- M M N E R VA A gateway to Melbourne's research publications}

Minerva Access is the Institutional Repository of The University of Melbourne

Author/s:

Pan, X;Zhao, L;Luo, J;Li, Y;Zhang, L;Wu, T;Smith, M;Dai, S;Jia, P

Title:

Access to bike lanes and childhood obesity: A systematic review and meta-analysis

Date:

2020-05-18

Citation:

Pan, X., Zhao, L., Luo, J., Li, Y., Zhang, L., Wu, T., Smith, M., Dai, S. \& Jia, P. (2020). Access to bike lanes and childhood obesity: A systematic review and meta-analysis. OBESITY REVIEWS, 22 (Suppl 1), https://doi.org/10.1111/obr.13042.

Persistent Link:

http://hdl.handle.net/11343/252412

License:

CC BY-NC-ND 